\title{
Numerical Study of Oil Spill in the Patos Lagoon Under Flood and Ebb Conditions
}

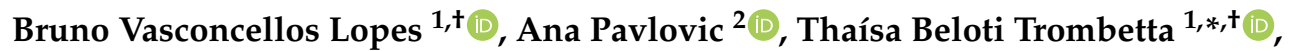 \\ Phelype Haron Oleinik ${ }^{1}$, , Caroline Barbosa Monteiro ${ }^{3}$, Ricardo Cardoso Guimarães ${ }^{1}$, \\ Douglas Vieira da Silva ${ }^{3}$ and Wiliam Correa Marques ${ }^{4,+}$ \\ 1 Escola de Engenharia, Universidade Federal do Rio Grande-FURG, Campus Carreiros, Av. Itália s/n Km 8, \\ Rio Grande CEP 96201-900, Brazil; lopesbruno13@gmail.com (B.V.L.); phe.h.o1@gmail.com (P.H.O.); \\ ricardo_guimaraes@hotmail.com (R.C.G.) \\ 2 Department of Industrial Engineering, University of Bologna, Viale Risorgimento 2, 40136 Bologna, Italy; \\ ana.pavlovic@unibo.it \\ 3 Instituto de Oceanografia, Universidade Federal do Rio Grande-FURG, Campus Carreiros, \\ Av. Itália s/n Km 8, Rio Grande CEP 96201-900, Brazil; monteirocbm@gmail.com (C.B.M.); \\ douglascpe@gmail.com (D.V.d.S.) \\ 4 Instituto de Matemática, Estatística e Física, Universidade Federal do Rio Grande-FURG, \\ Campus Carreiros, Av. Itália s/n Km 8, Rio Grande CEP 96201-900, Brazil; wilianmarques@furg.br \\ * Correspondence: thaisabtrombetta@gmail.com; Tel.: +55-53-98127-2637 \\ + These authors contributed equally to this work.
}

Received: 1 December 2018; Accepted: 24 December 2018; Published: 4 January 2019

\begin{abstract}
Facing great obstacles to eradicate environmental hazards generated by oil spills, it is crucial to establish actions against such accidents. In this context, the focus of this study is to analyze oil spills at the harbor region of Rio Grande, Rio Grande do Sul. The Easy Coupling Oil System (ECOS) model was used to model the oil spills under different environmental conditions simulated by the hydrodynamic model Telemac-3D, with the intention to identify the main forces controlling the movement of the oil slicks over a year of averaged hydrodynamic conditions from 2003 to 2015. The computational domain comprises the Patos Lagoon, the harbor area of Rio Grande and the Southern Brazilian Shelf. For the oil spill simulations, eight distinct events were defined considering both flood and ebb conditions in the estuarine region of the Patos Lagoon. The oil spill simulations showed that, in ebb conditions, the oil slick movement is mainly ruled by the currents, moving towards the outflow. After a few hours, the wind action makes the slick move towards the margins of the waterway. In flood conditions, on the other hand, the oil slick drifts to the interior of the estuary, following the dominant currents and the local winds.
\end{abstract}

Keywords: residence time; coastal lake; oil spill; ECOS; Telemac-3D

\section{Introduction}

The crescent utilization of the coastal areas for the most distinct economic purposes promotes the occurrence of hydrocarbons spills and associated environmental impact [1]. These spill events are related with the extraction, transport and storage of the oil in the sea and coastal regions [2].

The petroleum and derivatives are formed by hydrocarbons composed of aliphatic and aromatic substances with the presence of dissolved metals. Their properties and compositions are variable, according to the origin (natural or anthropic) and refinement process [3]. According to [4], the polycyclic aromatic hydrocarbons (PAHs), originated from fossil fuels, have toxic effects, acting as carcinogenic, mutagenic and teratogenic agents, besides having the capacity to bioaccumulate and biomagnify along the different trophic levels. 
According to [5], half of the world's oil is transported by vessels through the oceans. This amount was estimated to be approximately 31.5 billions of gallons per day. The entrance of oil into the marine environment varies between 1.7 and 8.8 million tons per day [5]. Marine tanker transportation represents $23.5 \%$ of the total amount of oil spilled in seas, and only approximately $10 \%$ of this amount is caused by accidents involving tankers [6].

Facing the difficulties to eliminate the possible accidents involving oil spills, mostly in areas where the transshipment of cargo in tankers occurs, it is important to establish quick action protocols against such accidents [7-9]. This demands precise forecasts of the consequences of eventual spills. In this way, numerical simulations that reproduce the behavior of the oil in the sea are mandatory [10].

Brazilian environmental law advocates that activities involving the production and distribution of petroleum and its derivatives at sea, must be substantiated by numerical simulation of oil spill scenarios. Such simulations are necessary for the definition of the indirect influence areas of this activities, and possible contamination locations. Such information will compose the Individual Emergency Plan (PEI), on which all the mitigation of the environmental damage is based [11].

Given the potential risks involving the Southern region of Brazil, the present study was directed to the harbor region of the Rio Grande city (Figure 1). The harbor is in the estuarine region of the Patos lagoon, and it is under the influence of meteorological and oceanographic physical forcing of the Southern Brazilian Shelf [12]. In 2016, the harbor of Rio Grande handled 38,223,751 tons of cargo, of which 4,602,636 tons were of liquid fuels [13].

This cargo handling makes the harbor of Rio Grande susceptible to accidents involving oil spills, adding environmental importance for this region. This work presents a case study of eight different oil spill events using numerical simulations. The case study is based on the coupled simulation of the three-dimensional hydrodynamic model Telemac-3D, part of the open TELEMAC-MASCARET modeling suite and a Lagrangian model of transportation and weathering of oil particles.

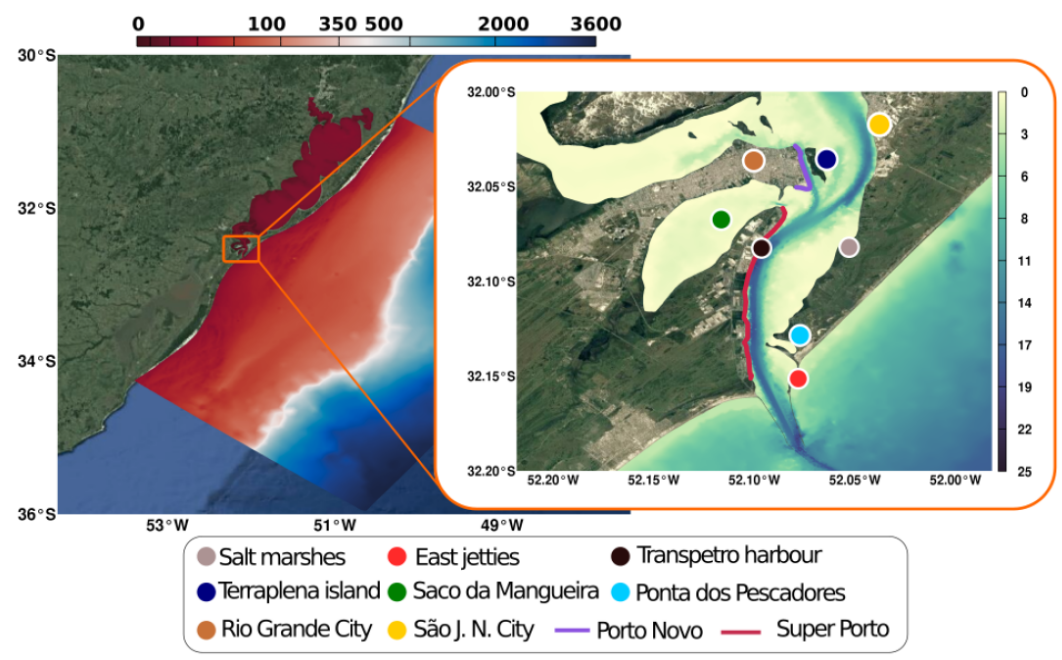

Figure 1. Representation of the computational domain. The color scale represents the bathymetry of the study area. The points and lines are references of oil spills.

\section{Methodology}

To perform the simulations, an unstructured mesh was developed, being limited on its coastal borders by the georeferenced shorelines of the Patos lagoon and the coastline of Rio Grande do Sul. The unstructured mesh allows the representation of the computational domain using nonuniform levels of refinement allowing one to have better resolution on areas of interest [14]. The length of the edge of the triangular elements varies from $11,000 \mathrm{~m}$ on deep ocean to $30 \mathrm{~m}$ at the location of the oil spill. The finest resolution is at the jetties of Rio Grande, with a nodal distance of $15 \mathrm{~m}$. The mesh has a 
total of 93,050 nodes. The vertical discretization of the domain consists of 15 equally spaced layers with varying depth (sigma levels).

The bathymetric data used was obtained from nautical charts (Patos Lagoon $-\mathrm{N}^{\circ}$ 2140, Pinhal to Rio Grande $-\mathrm{N}^{\circ}$ 2350, Rio Grande and Arroio Chuí- $\mathrm{N}^{\circ} 2112$ ) and coastal data from bathymetric surveys of the Brazilian Navy (LEPLAC).

\subsection{Numerical Model}

The numerical model used to simulate the hydrodynamics was Telemac-3D. This model is used for three-dimensional hydrodynamic studies of free-surface flows in rivers, estuaries, coastal and oceanic regions [15]. Telemac-3D solves the Navier-Stokes equations and the Mass Conservation equation considering the Boussinesq approximation to solve the momentum equations.

Following the methodology of [16], the hydrodynamic simulation used a time step of $90 \mathrm{~s}$ and the horizontal turbulent processes were simulated using the $\mathrm{k}-\epsilon$ turbulence model. To describe the oil drift processes, the ECOS (Easy Coupling Oil System) was used. This model has been being developed at the Universidade Federal do Rio Grande (FURG) since 2010. This model is in an advanced stage of development, and it is registered in the INPI (Instituto Nacional da Propriedade Industrial) under the license BR 51201300013 [17].

The ECOS represents the oil slick as a number of of discrete particles that mode independently in the water while still acting on each other to compute the processes of advection, scattering, and oil turbulence. The following section explain these processes.

\subsubsection{Advection}

The advection of the oil particles takes into account the transportation of the oil under the influence of currents and winds. The particles are also advected by the process of scattering and turbulent diffusion.

The meridional, zonal, and vertical components of the advective velocities of the $i$ th particle is calculated by the Equations (1)-(3), respectively:

$$
\begin{gathered}
U_{i}=k_{c} U_{c}+k_{w} U_{w}, \\
V_{i}=k_{c} V_{c}+k_{w} V_{w} \\
W_{i}=k_{c} W_{c}+w_{i}
\end{gathered}
$$

where $U_{c}, V_{c}$, and $W_{c}$ are the three orthogonal current components, $U_{w}$ and $V_{w}$, the wind components, and $k_{c}$ and $k_{w}$ are the drag coefficients of the current and the wind, respectively. ECOS uses the Stokes Law to compute the fall velocity of the oil particles [18]:

$$
w_{i}=\frac{d_{i}^{2} g\left(1-\frac{\rho_{o}}{\rho_{w}}\right)}{18 v_{w}}
$$

where $d_{i}$ is the diameter of the oil particle, $g$ is the acceleration of gravity, $\rho_{o}$ the oil density, $\rho_{w}$ the water density, and $v_{w}$, the dynamic viscosity of the sea water.

\subsubsection{Scattering}

Scattering is the horizontal expansion of the oil slick due to differential surface tensions acting on the water-oil interface. Thus, the scattering process represents the balance between the gravitational, inertial, and viscous forces, and the surface tension.

Currently, ECOS uses the classical formulation proposed by [19] to calculate the scattering velocities. The final formulation of the process was stated by [20], using the coefficients developed by $[10,21]$. 
The phenomenon is calculated in three stages. Firstly, the scattering coefficients $D_{x}$ and $D_{y}$ are calculated using Equation (5):

$$
D_{x}=D_{y}=\frac{\pi k_{2}^{2}}{16}\left(\frac{\Delta g V^{2}}{v_{w}^{2}}\right)^{\frac{1}{3}} \times \frac{1}{\sqrt{t}}
$$

where $V$ is the volume of the oil slick, $t$ is the time since the start of the spill, and $k_{2}$ is a coefficient that equals 0.725 [21].

The next step is to calculate the action radius of the scattering, $U_{r}$ and $V_{r}$, using Equations (6) and (7), respectively:

$$
\begin{aligned}
& U_{r}=\sqrt{\frac{2 D_{x}}{\Delta t}}, \\
& V_{r}=\sqrt{\frac{2 D_{y}}{\Delta t} .}
\end{aligned}
$$

Finally, the scattering velocities $U s_{i}$ and $V s_{i}$ are calculated using Equations (8) and (9), respectively:

$$
\begin{gathered}
U s_{i}=R_{1} \cos \left(2 \pi R_{2}\right) \times U_{r}, \\
V s_{i}=R_{1} \sin \left(2 \pi R_{2}\right) \times V_{r} .
\end{gathered}
$$

\subsubsection{Turbulent Diffusion}

ECOS uses a Mixing Length model modified for the oil as described by [22] to calculate the turbulent diffusion. Initially, the maximum distance $\Delta S$ that an oil particle can move in a time interval $\Delta t$ is defined (Equation (10)), then the velocity components $U d_{i}$ and $V d_{i}$ are calculated using Equations (11) and (12), respectively:

$$
\begin{aligned}
& \Delta S=R_{1} \sqrt{\left(12 D_{x} \Delta t\right)}, \\
& U d_{i}=\Delta S \cos \left(2 \pi R_{2}\right), \\
& V d_{i}=\Delta S \sin \left(2 \pi R_{2}\right) .
\end{aligned}
$$

\subsection{Initial and Boundary Conditions}

The hydrodynamic model was forced by atmospheric data from National Oceanic and Atmospheric Administration (NOAA ${ }^{1}$ ), oceanographic data from Hybrid Coordinate Ocean Model $\left(\mathrm{HyCOM}^{2}\right)$, tidal data from the OSU Tidal Inversion Software $\left(\mathrm{OTIS}^{3}\right)$, and river discharge data from the Agência Nacional de Águas (ANA ${ }^{4}$ ) database.

Initial conditions are the currents, salinity, and temperature from $\mathrm{HyCOM}$ with a spatial resolution of $0.75^{\circ} \times 0.75^{\circ}$. The oceanic boundaries were also forced by data from HyCOM, with temporal resolution of one day, and by tidal constituents from OTIS. The superficial boundary was forced by winds, atmospheric pressure, and air temperature from NOAA, with a spatial resolution of $2.5^{\circ} \times 2.5^{\circ}$ and temporal resolution of $6 \mathrm{~h}$. The river inlets were forced by daily time series of river discharge from ANA.

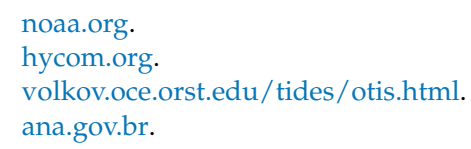




\subsection{Setup and Validation}

The hydrodynamic simulations were performed in two steps. The first was four 105-day long simulations executed to validate Telemac-3D for the study region. The second was a 365-day long simulation using daily averaged meteorological, oceanic, and fluvial data from the years 2003 to 2015.

For the case study oil spill simulations, two distinct hydrodynamic events were chosen: one with flood and the other with ebb conditions of the estuary of the Patos Lagoon. The oil spills started, for both simulations, at the Transpetro harbor terminal, located at coordinates $32^{\circ} 04^{\prime} 37.2^{\prime \prime} \mathrm{S}$ and $52^{\circ} 05^{\prime} 27.6^{\prime \prime} \mathrm{W}$, with a spilled volume of $20 \mathrm{~m}^{3}$ of oil.

The hydrodynamic simulations were performed for a period of 105 days, between 1 December 2010 and 15 February 2011, and their results were compared with field observations to validate the model. Tests were performed to calibrate the hydrodynamic model using four settings of following parameters: the wind friction coefficient and the bottom friction coefficient. Table 1 shows the values used for these tests.

Table 1. Simulation parameters.

\begin{tabular}{ccc}
\hline Simulation & $\begin{array}{c}\text { Wind Friction } \\
\text { Coefficient }\end{array}$ & $\begin{array}{c}\text { Bottom Friction } \\
\text { Coefficient }\end{array}$ \\
\hline V1F4 & $1 \times 10^{-5}$ & 0.04 \\
V1F5 & $1 \times 10^{-5}$ & 0.00 \\
V5F4 & $5 \times 10^{-6}$ & 0.04 \\
V5F5 & $5 \times 10^{-6}$ & 0.05 \\
\hline
\end{tabular}

To verify the model reproducibility, the hydrodynamic simulation result was compared with field observations of current and salinity series of the Patos Lagoon channel at the Praticagem Station, between the period of 5 January 2011 and 30 January 2011.

The current data were obtained using an Acoustic Doppler Current Profiler (ADCP) located at the navigation channel $14 \mathrm{~m}$ depth. To enhance the comparison between modeled and observed series, a Lanczos square filter, used to remove higher frequency oscillations (periods shorter than $12 \mathrm{~h}$ ), was applied. Salinity data were collected using a Temperature and Conductivity (CTD) sensor located at the same station of the CTD, but at $3 \mathrm{~m}$ depth.

Figure 2 compares observed series (black dots) with four different model settings' results (colored lines). The settings differ by the values used for the wind and bottom friction coefficient, calibrated in order to reduce the differences between model results and observations. From Figure 2, it is possible to notice a good agreement of the modeled results when compared to the observed data, even though the model outcome demonstrated a slight magnitude underestimation.

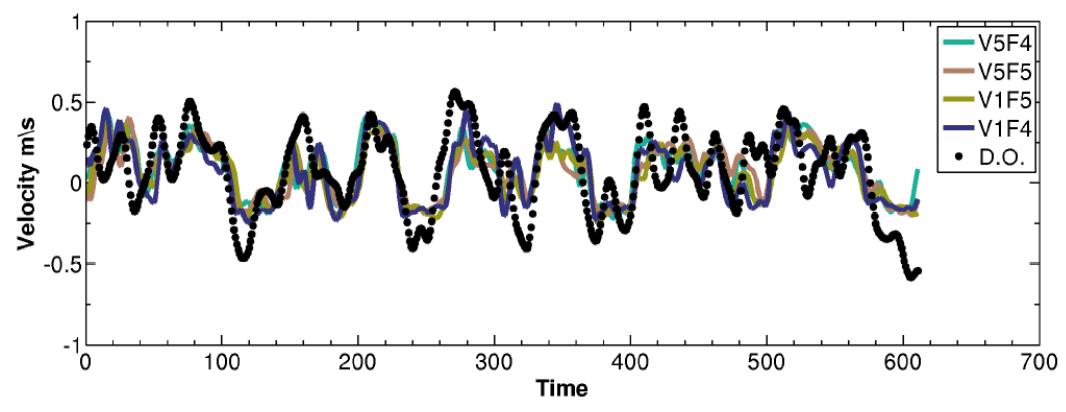

Figure 2. Cont. 


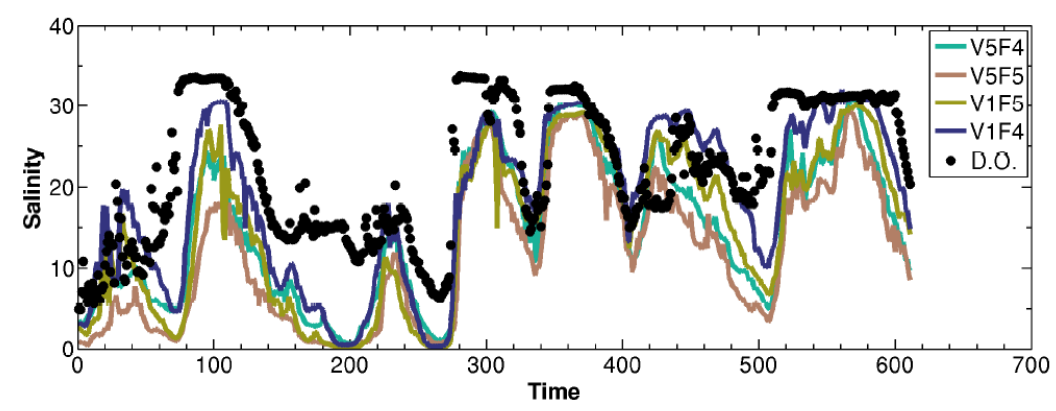

Figure 2. Comparison between observations (black dots) and model results (colored lines) for four parameters' settings. The plot shows the meridional component of currents above and salinity below at Praticagem Station.

The simulation performances were qualified using the methods proposed by $[16,23,24]$, computing the mean, absolute error, mean square error, coefficient correlation and the bias between the observations and model results. The V1F4 (blue line) simulation showed the best performance when compared to the other settings, as Table 2 shows.

Table 2. Calibration statistics.

\begin{tabular}{cccccc}
\hline & Parameters & V1F4 & V1F5 & V5F4 & V5F5 \\
\hline \multirow{4}{*}{ Current } & Mean & 0.066 & 0.059 & 0.082 & 0.080 \\
Velocity & Absolute Error & 0.155 & 0.161 & 0.158 & 0.159 \\
& Coefficient Correlation & 0.193 & 0.195 & 0.194 & 0.196 \\
& Bias & -0.008 & -0.014 & 0.008 & 0.007 \\
\hline \multirow{5}{*}{ Salinity } & 18.450 & 14.949 & 14.754 & 11.856 \\
& Mean & 5.740 & 8.019 & 7.976 & 10.622 \\
& Absolute Error & 7.466 & 9.864 & 9.525 & 12.109 \\
& Mean Square Error & 0.768 & 0.750 & 0.780 & 0.757 \\
& Coefficient Correlation & 0.750 & 0.652 & 0.645 \\
& Bias & -3.907 & -7.408 & -7.603 & -10.501 \\
\hline
\end{tabular}

The underestimated values of simulations results could be related to the use of constant coefficients of wind in the role mesh, absence of energy generated by the wind and absence of wave-current interaction. These factors have a large variability in the study area, but their implementation requires information that could not be obtained. Another cause could be the low resolution of the reanalysis products used, which does not reproduce the synoptic oscillations recurrent in the area.

Ref. [25] performed numerical simulations using reanalysis data at La Plata River region, observing that high intensity events were underestimated by $50 \%$ when compared with field observations. Ref. [23] attributed the low resolution of reanalysis products to the major source of errors, when compared with wind fields analyzed at the Mediterranean Basin.

The results verification indicates that, even with data limitations used to force the model, the simulation reproduces the observations' trends at the Patos Lagoon channel, making it possible to use these simulations to evaluate likely scenarios of fate and behavior of oil spill at the study area.

\section{Results}

The numerical simulation results using the V1F4 settings and daily averages between 2003 and 2015 exhibit attenuation of the wind and current components. As a consequence, the results differ from previous hindcast works in the Patos Lagoon Estuary, such as [26-29] works, based on realistic scenarios.

Wind pattern has a typical behavior along the Southern Brazilian Shelf with a dominant Northeast-Southwest influence due to the intermittent passage of frontal systems, e.g., [30-32]. 
Additionally, previous results obtained by $[32,33]$ indicate the dominance of the wind-driven coastal circulation over the Southern Brazilian Shelf with cycles from 3 to 15 days.

Comparative analysis between flood and ebb events shows ebb as the more frequent event, due to constant north wind effects and by the discharge of the tributary rivers of Patos Lagoon, resulting in an estuarine flux seaward. The flood conditions are associated with the south winds, which promotes secondary effects, resulting in flux towards the north region of the estuary. Relation between ebb and flood events and their circulation patterns were studied by [34-36], which described the estuarine circulation of the Patos Lagoon.

Figure 3 shows oil spills events (A, B, C and D) in ebb conditions, and the transported oil during the beginning hours has the seaward current as dominant, thus it can be observed in the first hour for all events. After some time, the wind begins to transport the oil to the channel margin. In all the events of oil spill in ebb condition, transport towards the ocean was not observed.

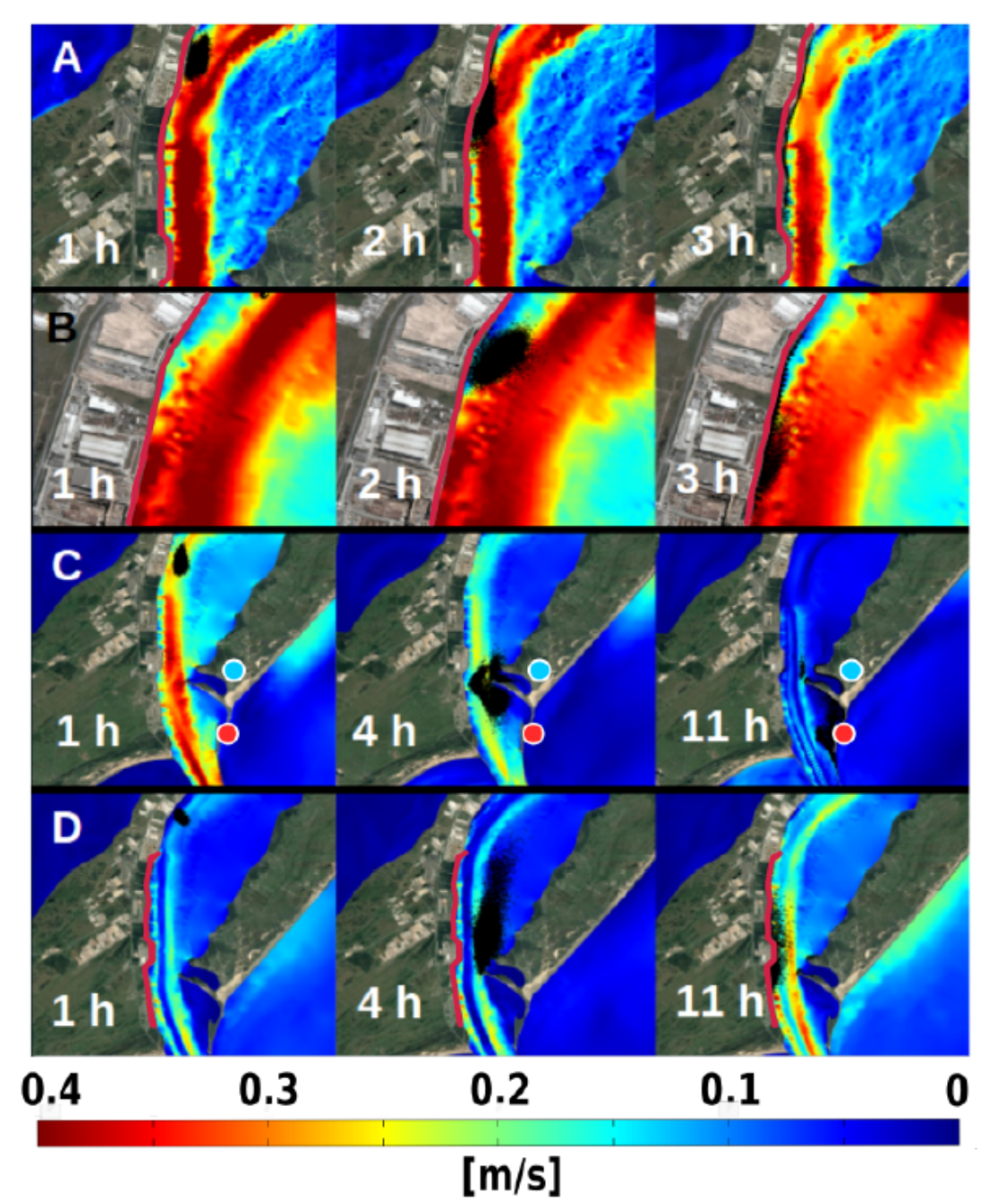

Figure 3. Simulation results of oil spill on ebb conductions (A-D). The oil (black dots) is advected seaward in all events. The color scale shows the current magnitude $\left(\mathrm{m} \mathrm{s}^{-1}\right)$, higher in the channel of the estuary.

The simulations' events A and B (Figure 3) presents high intensity winds; this causes a fast displacement of the oil towards the port, which at some point reaches the margin. The impacts verified are the economic losses in the directly influenced area, mostly due to the intense cargo transshipment in this location. 
Events C and D (Figure 3) show similar characteristics; however, the oil spill follows the current by a distance of $6000 \mathrm{~m}$ before starting to receive the influence of the wind. In event $\mathrm{C}$, the oil is transported to the east margin reaching the Ponta dos Pescadores, where salt marshes are present, and fishing is practiced around the São José do Norte city.

The salt marsh area was identified by [37] as vulnerable to coating by oil; they are closely related to the point reached by the oil at the simulations events $C$ and D. Event D showed that the oil is transported to the lower part of the Super Porto de Rio Grande. After that, the oil reaches the west margin. Direct impacts and chronicle contamination by the oil would influence the fishery and human health of the users of the estuary.

Figure 4 shows events (A, B, C and D) in flood conditions, where it is possible to observe the oil being transported towards the interior of the estuary, following the current. Some hours after the oil spill, the south winds increase their influence, and transport the oil to the north side of the estuary.

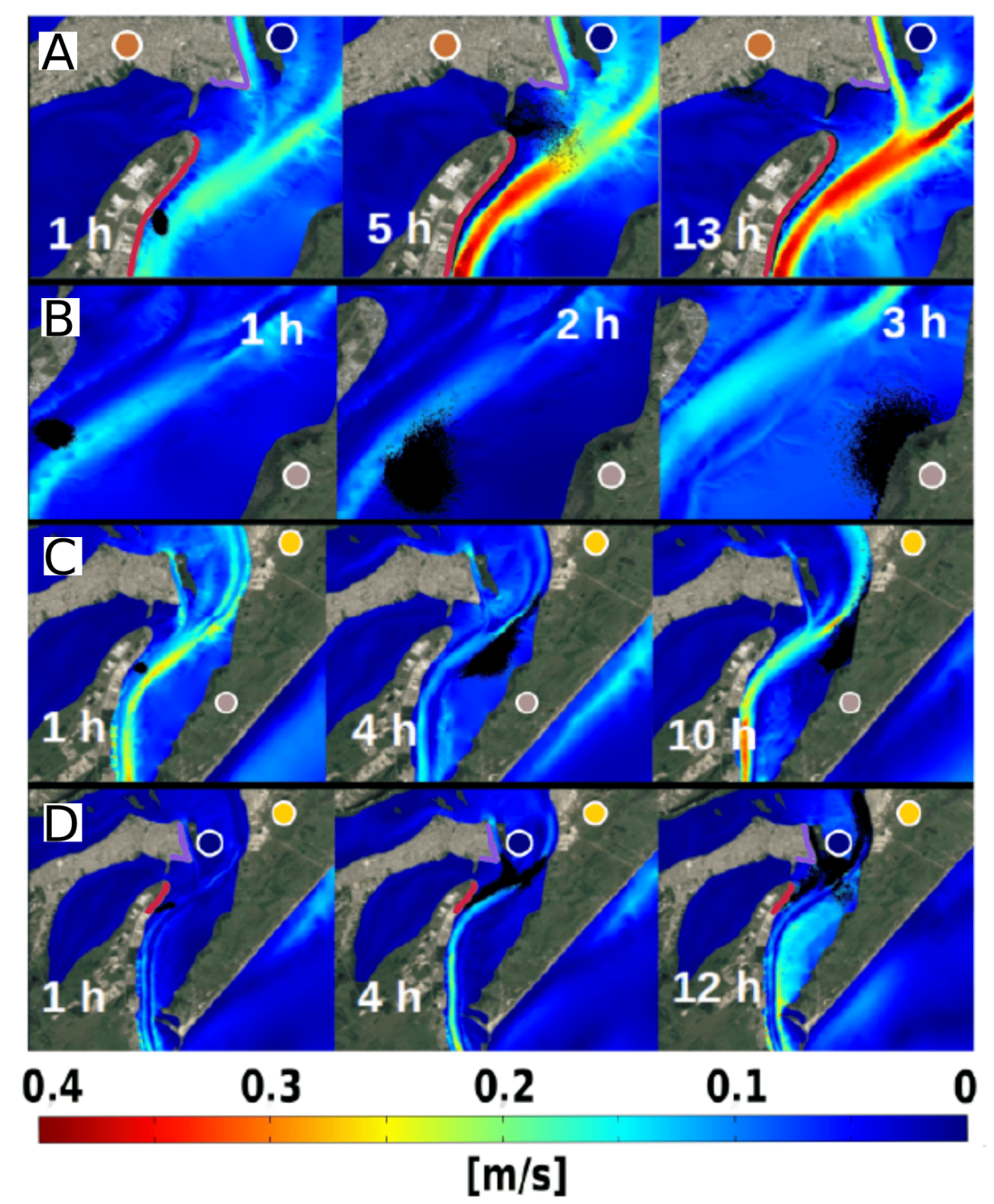

Figure 4. Simulation results of oil spill events on flood conductions (A-D). The oil (black dots) is advected seaward in all events. The color scale shows the current magnitude $\left(\mathrm{m} \mathrm{s}^{-1}\right)$, higher in the channel of the estuary.

Simulation A (Figure 4) shows the oil reaching parts of the Porto Novo of Rio Grande and being transported by the dominant current inside the Saco da Mangueira inlet. In the Saco da Mangueira, several economic activities are carried out, as the support to the industrial park of the Rio Grande city, mostly, shrimp fishing and leisure activities [36].

Simulations of events C and D (Figure 4) shows similar behaviors, and the oil is transported towards the interior of the Patos Lagoon estuary, reaching the Terraplena island, Porto Velho de Rio 
Grande and the urban zone of the São José do Norte. These events could cause direct impacts to the environment, as damages and impact to the population health and sea activities.

As mentioned previously, the risks of oil spills are diverse due to the toxic effects of the oil composition. The results shows that several areas of the estuary could be reached by the oil, where the pattern of circulation promotes the permanence of the oil in the system.

\section{Conclusions}

The Telemac-3D model showed the capacity to simulate the pattern of currents in the estuary of Patos Lagoon. Thus, the behavior of the oil spill simulated by the ECOS model could be used as a tool for environmental management and decision-making in case of incidents involving oil spill in the Patos Lagoon.

The fate of oil in ebb scenario has as major points the channel margin of the Super Porto de Rio Grande, the coastline parallel to the Farol Atalaia area and in the exit area of the east jetties, adjacent to São José do Norte city.

In the flood scenario, the transport of the oil after the spill had a higher variability, being Porto Velho de Rio Grande, coastline of Rio Grande city, Terrapleno island and the São José do Norte city as the most frequent fate of the oil.

Once the pattern of ebb and flood are characterized, as the wind and currents' effects over the oil trajectory, this article brought information about the fate of the oil reliable to orientation of response procedures in the case of oil spill on the transshipment area of the Porto of Rio Grande.

Author Contributions: The individual contributions to this paper were performed throughout conceptualization, B.V.L., A.P., T.B.T., P.H.O., C.B.M., R.C.G., D.V.d.S. and W.C.M.; Methodology, B.V.L. and P.H.O.; Software, B.V.L., R.C.G. and W.C.M.; Validation, B.V.L., A.P., C.B.M. and W.C.M.; Formal Analysis, B.V.L., A.P., T.B.T. and W.C.M.; Investigation, B.V.L., C.B.M., P.H.O. and W.C.M.; Resources, W.C.M.; Data Curation, B.V.L., T.B.T., R.C.G., A.P., W.C.M. and D.V.d.S.; Writing-Original Draft Preparation, B.V.L., T.B.T., P.H.O. and D.V.d.S.; Writing-Review and Editing, A.P., R.C.G. and W.C.M.; Visualization, B.V.L.; Supervision, W.C.M. and T.B.T.; Funding Acquisition, W.C.M. and A.P.

Funding: This research received no external funding.

Acknowledgments: The authors are grateful to the Centro de Hidrografia da Marinha (CHM) of the Brazilian Navy for the bathymetric data, the National Oceanic and Atmospheric Administration (NOAA) for the wind and wave data, and to the TELEMAC-MASCARET consortium for the continuous development of the modeling suite. This research was developed using the resources of the Centro Nacional de Supercomputação (CESUP), and the Laboratório Nacional de Computação Científica (LNCC-SDUMONT-2017-C01\#166515). This study was financed in part by the Coordenação de Aperfeiçoamento de Pessoal de Nível Superior—Brasil (CAPES)—Finance Code 001, and was supported by the Fundação de Amparo à Pesquisa do Estado do Rio Grande do Sul (FAPERGS) under contracts 17/2551-001159-7, and by the Conselho Nacional de Desenvolvimento Científico e Tecnológico (CNPq) under the grant $\mathrm{n}^{\circ}$ 304227/2016-1.

Conflicts of Interest: The authors declare no conflict of interest. The funders had no role in the design of the study, in the analyses or interpretation of data, in the writing of the manuscript and in the decision to publish the results.

\section{References}

1. Gurjar, B.R.; Sharma, R.K.; Ghuge, S.P.; Wate, S.R.; Agrawal, R. Individual and Societal Risk Assessment for a Petroleum Oil Storage Terminal. J. Hazard. Toxic Radioact. Waste 2015, 19, 4015003. [CrossRef]

2. Lopes, C.F.; Milanelli, J.C.C.; Poffo, I.R.F. Ambientes Costeiros Contaminados Por óleo: Procedimentos de Limpeza-Manual de Orientação; Secretaria de Estado do Meio Ambiente: São Paulo, Brazil, 2007; p. 120.

3. Thomas, J.E. Fundamento de Engenharia de Petróleo. Editora Rio de Janeiro Interciência Petrobras, 2nd ed.; Jose Eduardo Thomas: Rio de Janeiro, Brazil, 2004; p. 267.

4. Caruso, M.S.F.; Alaburda, J. Hidrocarbonetos policíclicos aromáticos-benzo(a)pireno: Uma revisão. Rev. Inst. Adolfo Lutz 2008, 67, 1-27.

5. Clark, R.B. Marine Pollution; Oxford University Press: New York, NY, USA, 2001. 
6. Bollmann, M.; Bosch, T.; Colijn, F.; Ebinghaus, R.; Froese, R.; Güssow, K.; Khalilian, S.; Krastel, S.; Körtzinger, A.; Langenbuch, M.; et al. World Ocean Review_Living with the Oceans; Maribus GmbH: Hamburg, Germany, 2010; pp. 232-236.

7. Stringari, C.E.; Correa Marques, W.; Eidt, R.T.; Mello, L.F. Modeling an Oil Spill along the Southern Brazilian Shelf: Forcing Characterization and Its Influence on the Oil Fate. Int. J. Geosci. 2013, 4, 397-407. [CrossRef]

8. Boehm, P.D.; Murray, K.J.; Cook, L.L. Distribution and Attenuation of Polycyclic Aromatic Hydrocarbons in Gulf of Mexico Seawater from the Deepwater Horizon Oil Accident. Environ. Sci. Technol. 2016, 50, 584-592. [CrossRef]

9. Liu, X.; Guo, M.; Wang, Y.; Yu, X.; Guo, J.; Tang, C.; Hu, X.; Wang, C.; Li, B. Assessing pollution-related effects of oil spills from ships in the Chinese Bohai Sea. Mar. Pollut. Bull. 2016, 110, 194-202. [CrossRef] [PubMed]

10. Sebastião, P.; Soares, C.G. Modeling the Fate of Oil Spills at Sea. Spill Sci. Technol. Bull. 1995, 2, $121-131$. [CrossRef]

11. IBAMA. Informação Técnica ELPN/IBAMA N 023/02-Modelagem de Derramamento de Óleo no Mar; Ministerio do meio Ambiente: Rio de Janeiro, Brazil, 2002.

12. Möller, O.O.; Casting, P.; Salomon, J.C.; Lazure, P. The influence of local and non-local forcing effects on the subtidal circulation of the Patos Lagoon. Estuaries 2001, 24, 275-289. [CrossRef]

13. SUPRG. Superintendência do Porto de Rio Grande. Movimentação por Segmento de Carga ano 2016; SUPRG: Rio Grande, Brazil, 2017.

14. Lynch, D.R.; Ip, J.T.C.; Naimie, C.E.; Werner, F.E. Comprehensive coastal circulation model with application to the Gulf of Maine. Cont. Shelf Res. 1996, 16, 875-906. [CrossRef]

15. Hervouet, J.M. Hydrodynamics of Free Surface Flows: Modelling with the Finite Element Method; John Wiley \& Sons: Hoboken, NJ, USA, 2007.

16. Marques, W.C.; Stringari, C.E.; Kirinus, E.P.; Möller, O.O., Jr.; Toldo, E.E., Jr.; Andrade, M.M. Numerical modeling of the Tramandaí beach oil spill, Brazil—Case study for January 2012 event. Appl. Ocean Res. 2017, 65, 178-191. [CrossRef]

17. Marques, W.C.; Stringari, C.E.; Mello, L.F. ECOS-Easy Coupling Oil System. Patente: Programa de Computador. Título: "ECOS_Easy Coupling Oil System"; Universidade Federal do Rio Grande-FURG: Rio Grande, Brazil, 2013.

18. French-McCay, D. Oil spill impact modeling: Development and validation. Environ. Toxicol. Chem. 2004, 23, 2441-2456. [CrossRef]

19. Fay, J.A. The spread of oil slicks on a calm sea. In Oil Sea; Springer: Boston, MA, USA, 1969; pp. 53-54.

20. Proctor, R.; Elliot, A.J.; Fiather, R.A. Forecast and hindcast simulations of the Braer oil spill. Mar. Pollut. Bull. 1994, 28, 219-229. [CrossRef]

21. Flores, H.; Andreatta, A.; Llona, G.; Saavedra, I. Measurements of oil spill spreading in a wave tank using digital image processing. Trans. Ecol. Environ. 1998, 27, 9. [CrossRef]

22. Al-Rabeh, A.H.; Cekirge, H.M.; Water, N.G. A stochastic simulation model of oil spill fate and transport. Appl. Math. Model. 1989, 13, 322-329. [CrossRef]

23. Sutherland, J.; Wallingford, H.R. Cosmos Modelling and the Development of Model Performance Statistics; TR121-EC MAST Project $n^{\circ}$ MAS3-CT97-0086; HR Wallingford Ltd.: Wallingford, UK, 2001; pp. 1-4.

24. Oleinik, P.H.; Marques, W.C.; Kirinus, E.d.P. Estimate of the Wave Climate on the Most Energetic Locations of the South-Southeastern Brazilian Shelf. Defect Diffus. Forum 2017, 370, 130-140. [CrossRef]

25. Simionato, C.G.; Meccia, V.L.; Dragani, W.C.; Nuñez, M.N. On the use of the NCEP/NCAR surface winds for modeling barotropic circulation in the Río de la Plata Estuary. Estuar. Coast. Shelf Sci. 2006, 70, 195-206. [CrossRef]

26. Marques, W.C.; Fernandes, E.H.; Moller, O.O., Jr.; Moraes, B.C.; Malcherek, A. Dynamics of the Patos Lagoon coastal plume and its contribution to the deposition pattern of the southern Brazilian inner shelf. J. Geophys. Res. 2010. [CrossRef]

27. Marques, W.C.; Fernandes, E.H.L.; Rocha, L.A.O. Straining and advection contributions to the mixing process in the Patos Lagoon estuary, Brazil. J. Geophys. Res. Oceans 2011, 116, 1-23. [CrossRef]

28. Fernandes, E.H. Modelling the Hydrodynamics of the Patos Lagoon, Brazil. Ph.D. Thesis, University of Plymouth, Plymouth, UK, 2001. 
29. Fernandes, E.H.L.; Cecíclio, R.O.; Schiller, R.V. Estudo da influência da obra de convergência dos Molhes da Barra de Rio Grande sobre a circulação hidrodinâmica do Estuário da Lagoa dos Patos. VETOR- Revista de Ciências Exatas e Engenharias 2007, 15, 49-57.

30. Soares, I.D.; Kourafalou, V.; Lee, T.N. Circulation on the western South Atlantic continental shelf: 1. Numerical process studies on buoyancy. J. Geophys. Res. Oceans 2007, 112. [CrossRef]

31. Soares, I.D.; Kourafalou, V.; Lee, T.N. Circulation on the western South Atlantic continental shelf: 2. Spring and autumn realistic simulations. J. Geophys. Res. Oceans 2007, 112. [CrossRef]

32. Costa, R.L.; Möller, O.O. Estudo da estrutura e da variabilidade das correntes na área da plataforma interna ao largo de Rio Grande (RS, Brasil), no sudoeste do Atlântico Sul, durante a primavera-verão de 2006-2007. Revista da Gestão Costeira Integrada 2011, 11, 273-281. [CrossRef]

33. Mello, L.F.; Stringari, C.E.; Eidt, R.T.; Marques, W.C.; Costa, R.L.; Moller, O. Desenvolvimento De Modelo Lagrangeano De Transporte De Óleo: Estruturação e Acoplamento ao Modelo Hidrodinâmico TELEMAC3D. Pesquisas Aplicadas em Modelagem Matemática 2012, 1, 1-21.

34. Moller, O.O.; Lorenzzentti, J.A.; Stech, J.; Math, M.M. The Patos Lagoon summertime circulation and dynamics. Cont. Shelf Res. 1996, 16, 335-351. [CrossRef]

35. Marques, W. Padrões de Variabilidade Temporal nas Forçantes da Circulação e Seus Efeitos na Dinâmica da Lagoa dos Patos, Rio Grande do Sul, Brasil. Ph.D. Thesis, Universidade Federal do Rio Grande, Rio Grande do Sul, Brazil, 2005.

36. Monteiro, I.O.; Pearsom, M.; Möller, O.O.; Fernandes, E.H.L. Hidrodinâmica do Saco da Mangueira: mecanismos que controlam as trocas com o estuário da Lagoa dos Patos. Atlântica (Rio Grande) 2006, 27, 8-101.

37. Nogueira, R.X.d.S.; Costa, C.S.B. Sigmar: Aplicação e análise de sensibilidade das marismas a derrames de óleo. In XI Simpósio Brasileiro de Sensoriamento Remoto; FURG: Belo Horizonte, Minas Gerais, Brazil, 2003; pp. 1617-1619.

(C) 2019 by the authors. Licensee MDPI, Basel, Switzerland. This article is an open access article distributed under the terms and conditions of the Creative Commons Attribution (CC BY) license (http://creativecommons.org/licenses/by/4.0/). 